Eur. J. Clin. Chem. Clin. Biochem.

Vol. 31, 1993, pp. 289-293

(C) 1993 Walter de Gruyter \& Co.

Berlin · New York

\title{
Assay of Antinuclear Antibodies by ELISA Using Nuclei as Antigen
}

\author{
By J. Ara and R. Ali
}

Department of Biochemistry, Faculty of Medicine, Aligarh Muslim University, Aligarh, India

(Received September 16, 1992)

Summary: An enzyme-linked immunosorbent assay to detect antinuclear antibodies in the sera of patients with autoimmune diseases is described. Goat liver nuclei were immobilized on polystyrene plates and antinuclear antibodies were used to standardize the assay. The effects of variables, such as the nuclei concentration, conditions of nuclei storage, and the length of the incubation period were investigated on the assay. Prototype sera with known antibody specificity were used to evaluate the assay. The method described is highly sensitive, autoantibodies being detectable at serum dilutions of $1: 1000$ or higher. According to the intra- and inter-assay coefficient of variation, the results were highly reproducible.

\section{Introduction}

Enzyme immunoassays have been successfully employed for the quantitation of human autoantibodies of defined specificities using purified antigen adsorbed on a solid matrix (reviewed in 1.c. (1)). Some variations of the procedure include the use of nylon beads as the solid support $(2-4)$ instead of a conventional polystyrene surface, and the use of a fluorogenic substrate (5) for the evaluation of enzyme activity.

In the present work, an enzyme-linked immunosorbent assay (ELISA) was evaluated as an alternative to the fluorescent antinuclear antibody (FANA) as-

1) List of antigens

$\begin{array}{ll}\text { nDNA }= & \text { native DNA } \\ \text { U1snRNP = } & \ldots \text { small nuclear ribonucleoprotein } \\ \text { Sm } & \text { an antigen, named from the initials of the } \\ & \text { patient who showed corresponding antibod- } \\ & \text { ies; a nuclear glycoprotein } \\ = & \text { antinuclear antibodies } \\ \text { ANA }= & \text { Ribonucleoprotein } \\ \text { RNP } & \text { an antigen } \mathrm{B} \text {, characterized by sera of certain } \\ \text { SS-B/La }= & \text { patients with Sjögren syndrome (SS) } \\ \text { SS-A/Ro }= & \text { an antigen A, characterized by sera of certain } \\ & \text { patients with Sjögren syndrome (SS) } \\ \text { Scl-70 }= & \text { an antigen of } M_{\mathrm{r}}=70.000, \text { identified by sera } \\ & \text { of certain patients suffering from scleroderma } \\ & \text { (Scl) }\end{array}$

say. Purified nuclei from goat liver were immobilized on polystyrene plates to detect antinuclear antibodies (ANA) $)^{1}$ ) in patients with systemic lupus erythematosus. The effects of the nuclei concentration, storage of nuclei below $0^{\circ} \mathrm{C}$, and the length of the incubation period was investigated on the assay. Sera from patients with systemic lupus erythematosus gave positive tests. In addition to the sera containing antinuclear antibodies, prototype sera with antibody specificity ${ }^{1}$ ) to nDNA, U1snRNP, Sm, nucleosomes, centromere, ANA (RNP, SS-B/La, SS-A/Ro) and Scl-70 autoantigens were used in this study. Positive results were obtained with these samples. Sera from normal individuals were used as controls.

\section{Materials and Methods \\ Materials}

Polystyrene plates from Dynatech, USA, were used as the solid support for antigen binding. Anti-human IgG alkaline phosphatase conjugate, poly $D$-lysine, poly $D$-glutamate, calf thymus DNA and bovine serum albumin were from the Sigma Chemical Company, USA. $p$-Nitrophenyl phosphate was obtained from the C.S. I. R. Centre for Biochemicals, New Delhi. Nonidet P40 was from BDH Chemicals, England. A Dynatech ELISA microplate reader MR 600 was used for absorption measurements. 


\section{Sera specimens}

Normal human sera and sera from patients with systemic lupus erythematosus who met the preliminary criteria of the American Rheumatism Association for this disease (6), were obtained as described elsewhere (7). All sera were stored at $-20^{\circ} \mathrm{C}$ until examined and were decomplemented before use by heating at $56^{\circ} \mathrm{C}$ for $30 \mathrm{~min}$. Prototype sera were obtained from Centers for Disease Control, Atlanta, Georgia, USA, and were rehydrated by adding $0.5 \mathrm{ml}$ of distilled water.

\section{Preparation of antigen}

Goat liver nuclei were isolated as described earlier (8). The isolated nuclei were suspended in $0.25 \mathrm{~mol} / 1$ sucrose, $3 \mathrm{mmol} / 1$ calcium chloride solution $(8.0 \mathrm{ml})$ and carefully layered over $3.0 \mathrm{ml}$ of Ficoll solution $(1.0 \mathrm{~kg} / \mathrm{l}$ in the sucrose/calcium chloride solution). The suspension was centrifuged at $700 \mathrm{~g}$ for $10 \mathrm{~min}$ and the purified nuclei were collected at the bottom of the centrifuge tube. The purified nuclei were inspected under the light microscope using haematoxylin stain.

\section{Enzyme-linked immunosorbent assay}

The technique of Aotsuka et al. (9) was used for the detection and quantitation of anti-DNA antibodies. Direct binding of antinuclear antibodies to nuclei as antigen (ANA-ELISA) was determined essentially as previously described (5). A polystyrene microtitre plate was incubated with $50 \mu$ l nuclear suspension (1000 nuclei/ $50 \mu \mathrm{l}$ in carbonate-bicarbonate buffer, $\mathrm{pH} 9.6$ ) for $2 \mathrm{~h}$ at room temperature and overnight at $4{ }^{\circ} \mathrm{C}$. The plate was washed three times with saline-Tween 20 and unoccupied sites were blocked with $10 \mathrm{~g} / \mathrm{l}$ bovine serum albumin in saline-Tween 20 for $6 \mathrm{~h}$. Decomplemented sera, dilution in saline-Tween 20 , were adsorbed for $2 \mathrm{~h}$ and overnight at $4^{\circ} \mathrm{C}$. The unbound material was washed four times with saline-Tween 20 and antihuman alkaline phosphatase conjugate $(1: 1500$ dilution in saline-Tween 20) was added. After $2 \mathrm{~h}$ at room temperature, the plate was washed three times with saline-Tween 20 . The substrate ( $p$-nitrophenyl phosphate, $5 \mathrm{mmol} / \mathrm{l}$ in carbonate buffer containing $2 \mathrm{mmol} / \mathrm{l}$ magnesium chloride, $\mathrm{pH} 9.5$ ) was added and absorbance was recorded at $410 \mathrm{~nm}$ after appropriate colour development. In each step $100 \mu$ l of solution was added and each sample was run in duplicate. The control wells were treated similarly but were devoid of antigen. Sera were tested at a dilution of $1: 1000$ unless mentioned otherwise.

\section{Data analysis}

Values obtained with 25 normal healthy individuals were used for determining the cut off level for distinguishing antibodypositive and antibody-negative samples. A value of twice the standard deviation above the mean, i.e. 0.20 , was chosen as a cut off value. A test sample was positive if the mean absorbance of duplicate measurements was greater than 0.20 and negative if the mean absorbance was lower.

\section{Accuracy and precision studies}

The reproducibility of the assay procedure was ascertained by determining the intra- and inter-assay coefficient of variation for three normal and seven antinuclear antibody positive systemic lupus erythematosus sera. These samples were tested seven times in one day in order to determine the intra-assay coefficient of variation, whereas testing of the same samples for seven consecutive days gave the inter-assay coefficient of variation.

\section{Results}

Nuclei from goat liver were used as antigen for the ELISA. The isolated nuclei were $90 \%$ pure, based on staining with haematoxylin, and the total particle count. Mitochondria and lysosomal particles accounted for less than $0.1 \%$ of the total particles in the nuclear preparations. Small amorphous components were present in amounts ranging from $1-8 \%$. A series of preliminary experiments were carried out to determine the effect of certain variables on assay procedure.

\section{Storage of nuclei}

When the ELISA was carried out with nuclei that had been stored up to two weeks at $-20^{\circ} \mathrm{C}$, almost no change in antibody binding was observed. However, a considerable decrease in binding was observed when the nuclei had been stored for longer periods (fig. 1). It is suggested that isolated nuclei stored at $-20^{\circ} \mathrm{C}$ can be used for the ELISA for about two weeks without appreciable loss in antigenicity.

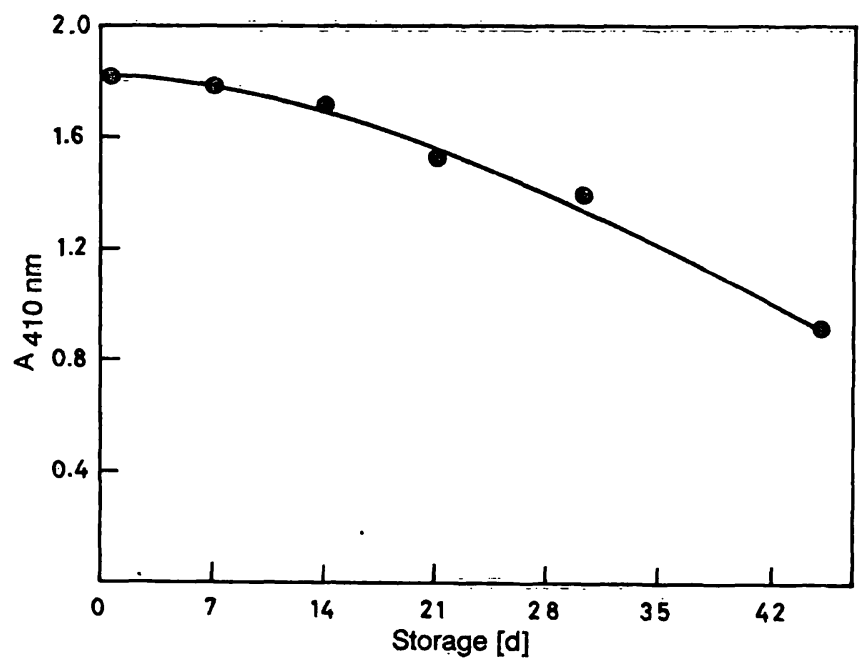

Fig. 1. Effect of incubation on antibody activity of isolated nuclei. Isolated nuclei were stored at below $0^{\circ} \mathrm{C}$ for different time intervals.

\section{Fixing of nuclei}

The nuclei become tightly adsorbed to the polystyrene surface. Repeated washing of adsorbed nuclei with saline-Tween 20 had almost no effect on the nuclei count. Binding of nuclei to the polystyrene surface was found to be $75-80 \%$ of added nuclei (fig. 2).

\section{Concentration of nuclei}

The ELISA was performed with increasing concentrations of nuclei at three different dilutions of two antinuclear antibody-positive systemic lupus erythe- 


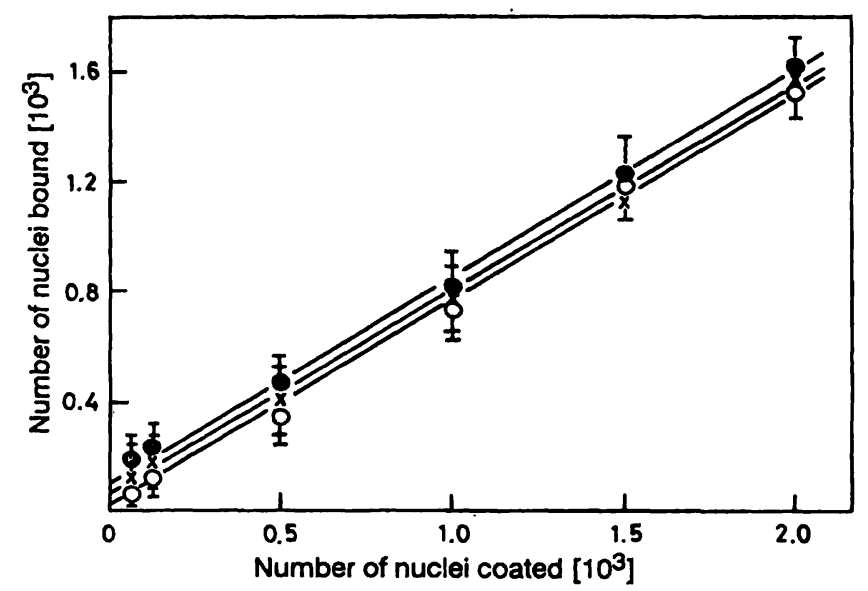

Fig. 2. Kinetics of adsorption of nuclei on polystyrene plate. The wells of the microtitre plate were coated with different concentrations of nuclei, and the number of nuclei adsorbed were determined by their count in the supernatant before (-0-) and after (-0-), (-x-) washing. The data represent a mean $\pm S$. D. of three determinations.

matosus sera. Antibody binding reached a maximum at 1000 nuclei bound per well. Further increases in the concentration of bound nuclei were accompanied by a marked decrease in antibody binding (fig. 3). The antibody binding profile was similar with different dilutions of each serum. In view of the sudden drop in antibody binding following any attempt to increase the coating above 1000 nuclei/well, the experiment was repeated three times to ascertain data reproducibility. Each time an almost identical profile was obtained.

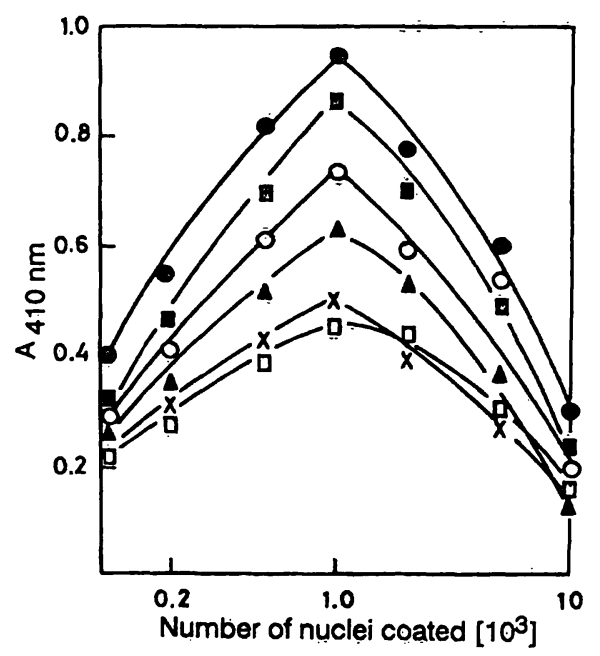

Fig. 3. Evaluation of the critical concentration of nuclei for the antinuclear antibody ELISA. Three different dilutions of two systemic lupus erythematosus sera $(-\bullet-)$, $(-0-),(-x-)$ and $(-\square-),(-\Delta-),(-\square-)$.

\section{ANA-ELISA}

Normal human sera, and sera of systemic lupus erythematosus patients with different level of antibody activity, were tested for antinuclear antibodies with the ELISA at various dilutions of serum. Ten out of twelve $(83 \%)$ systemic lupus erythematosus patients were positive for antibodies to antinuclear antibodies when purified nuclei were used as antigen. In figure 4 , titrations of three sera from systemic lupus erythematosus patients are compared with a normal human serum. The ELISA was also carried out with samples of systemic lupus erythematosus sera, using nDNA as antigen. Figure 5 shows the results obtained with various antibody-positive systemic lupus erythematosus sera.

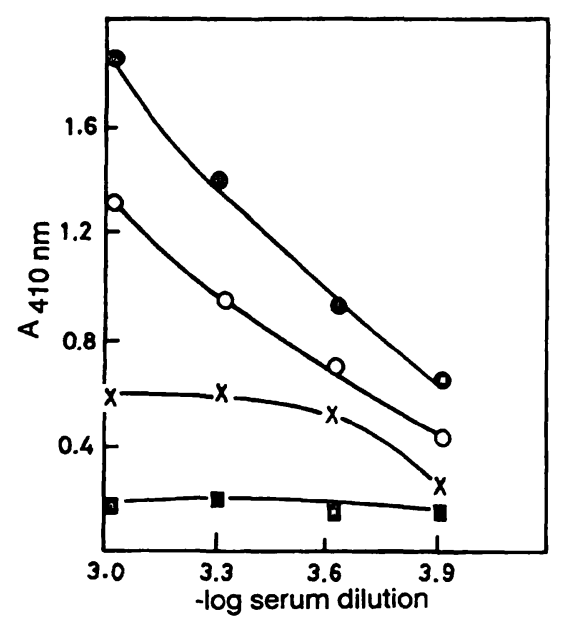

Fig. 4. Direct binding assay of antinuclear antibodies. (-0-), $(-0-),(-x-)$ antinuclear antibody-positive systemic lupus erythematosus serum with different levels of antibody activity. ( - a - ) normal human serum.

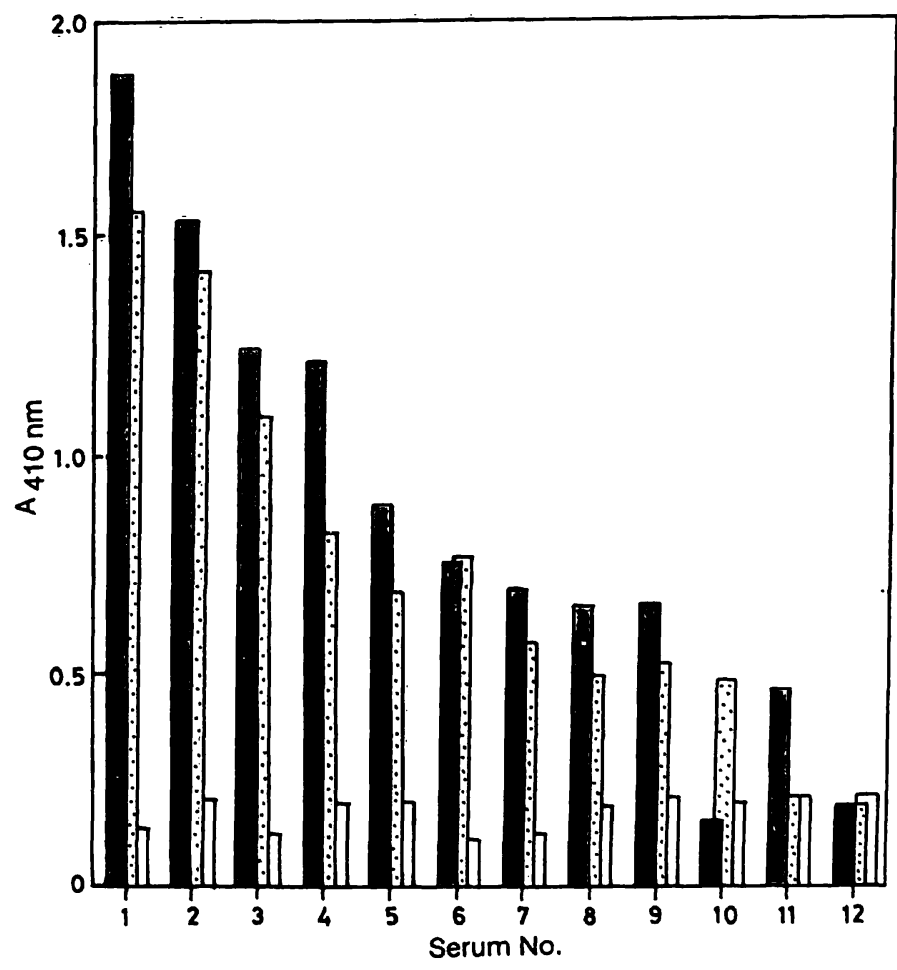

Fig. 5. Antibody binding profile of twelve systemic lupus erythematosus sera. Native DNA (四) and purified nuclei (a). Normal human serum with either of the antigens (a). 
The reference sera from the Centers for Disease Control, Atlanta, Georgia, USA, with antibody specificity for nDNA, RNP, Sm, nucleolus, centromere, ANA (RNP, SS-B/La, SS-A/Ro) and Scl-70 were analysed for their antibody content against nuclei, using the ELISA. All the prototype sera demonstrated strong antibody binding. The characteristic of reference sera as provided by the supplier and the titre obtained by ANA-ELISA are shown in table 1. The end point titre for individual sera is expressed as the mean of duplicate samples. Normal human sera and sera from patients with non-autoimmune diseases (25 serum samples) were negative for antinuclear antibodies.

Tab. 1. Comparison of the antinuclear antibody (ANA) reactivity of the FANA and the ANA-ELISA, using prototype sera

\begin{tabular}{llrr}
\hline $\begin{array}{l}\text { ANA-human } \\
\text { reference } \\
\text { serum No. }\end{array}$ & $\begin{array}{l}\text { Antibody } \\
\text { activity } \\
\text { against }\end{array}$ & $\begin{array}{l}\text { FANA } \\
\text { median } \\
\text { titre* }\end{array}$ & \multicolumn{1}{l}{$\begin{array}{l}\text { ANA- } \\
\text { ELISA } \\
\text { titre }\end{array}$} \\
\hline 1. & nDNA & $1: 512$ & $1: 3200$ \\
2. & ANA** & $1: 320$ & $1: 1600$ \\
3. & U1snRNP & ID $1: 64$ & $>1: 3200$ \\
4. & Sm & ID $1: 64$ & $>1: 3200$ \\
5. & Nucleolar & $1: 256$ & $1: 3200$ \\
6. & Centromere & $1: 640$ & $1: 1600$ \\
7. & Scl-70 & ID $1: 4$ & $1: 3200$ \\
\hline
\end{tabular}

* Provided by the Centers for Disease Control, Georgia, USA. ** U1RNP/SSB-La/SSA-Ro

$\mathrm{ID}=$ immunodiffusion

Tab. 2. Reproducibility data for antinuclear antibody assay of systemic lupus erythematosus and normal human sera

\begin{tabular}{|c|c|c|}
\hline \multirow{2}{*}{$\begin{array}{l}\text { Serum } \\
\text { No. }\end{array}$} & \multicolumn{2}{|c|}{ Mean absorbance \pm S.D. } \\
\hline & Intra-assay & Inter-assay \\
\hline \multicolumn{3}{|c|}{ Systemic lupus erythematosus } \\
\hline 1. & $\begin{array}{l}0.825 \pm 0.011 \\
(1.33)\end{array}$ & $\begin{array}{l}0.840 \pm 0.030 \\
(3.57)\end{array}$ \\
\hline 2. & $\begin{array}{l}0.754 \pm 0.009 \\
(1.19)\end{array}$ & $\begin{array}{l}0.715 \pm 0.025 \\
(3.49)\end{array}$ \\
\hline 3. & $\begin{array}{l}0.630 \pm 0.012 \\
(1.90)\end{array}$ & $\begin{array}{l}0.695 \pm 0.035 \\
(5.03)\end{array}$ \\
\hline 4. & $\begin{array}{l}0.654 \pm 0.010 \\
(1.52)\end{array}$ & $\begin{array}{l}0.621 \pm 0.032 \\
(5.15)\end{array}$ \\
\hline 5. & $\begin{array}{l}0.454 \pm 0.008 \\
(1.76)\end{array}$ & $\begin{array}{l}0.520 \pm 0.030 \\
(5.76)\end{array}$ \\
\hline 6. & $\begin{array}{l}0.385 \pm 0.008 \\
(2.15)\end{array}$ & $\begin{array}{l}0.430 \pm 0.050 \\
(11.62)\end{array}$ \\
\hline 7. & $\begin{array}{l}0.390 \\
(2.30)\end{array}$ & $\begin{array}{l}0.380 \pm 0.031 \\
(8.15)\end{array}$ \\
\hline \multicolumn{3}{|c|}{ Normal human sera } \\
\hline 8 & $\begin{array}{l}0.180 \pm 0.004 \\
(2.22)\end{array}$ & $\begin{array}{l}0.180 \pm 0.020 \\
(11.1)\end{array}$ \\
\hline 9. & $\begin{array}{l}0.220 \pm 0.002 \\
(0.909)\end{array}$ & $\begin{array}{l}0.250 \pm 0.020 \\
(8.00)\end{array}$ \\
\hline 10. & $\begin{array}{l}0.195 \pm 0.005 \\
(2.56)\end{array}$ & $\begin{array}{l}0.200 \pm 0.020 \\
(10.0)\end{array}$ \\
\hline
\end{tabular}

The values in parentheses represent coefficient of variation. Serum dilution was $1: 1000$.

\section{Precision}

Table 2 shows the intra- and inter-assay coefficients of variation for the measurement of antinuclear antibodies in seven positive systẹmic lupus erythematosus sera. A high degree of reproducibility of the assay procedure is evident from the data.

\section{Discussion}

The fluorescent antinuclear antibody (FANA) technique of Coons \& Kaplan (10) has become important as a widely used method for detecting antinuclear antibodies in the sera of patients with autoimmune diseases. Despite being the established method for detecting and quantifying antibodies, FANA has certain limitations, e.g. the use of fluorescent microscopy, wide variation in reagent quality, and the lack of a standard substrate for detecting a variety of autoantibodies $(11,12)$.

The studies reported here indicate that the identification of antibodies to nuclear antigens can be conveniently carried out with the ELISA, employing purified nuclei as the source of antigen.

In preliminary studies we observed a nearly linear relationship between antibody binding and nuclei concentration up to 1000 nuclei/well; further increases in the concentration of bound nuclei were accompanied by a marked decrease in antibody binding. Re-testing of sera at different dilutions yielded similar binding profile. It is possible that at higher concentrations the nuclei were adsorbed in layers which were easily lost during washing.

Sera of 12 systemic lupus erythematosus patients were examined with the ELISA, using nDNA and purified nuclei as the antigens. With two exceptions, a high titre of antibody binding against each of these two antigens was observed. One patient displayed high titre antibodies to nuclei, but showed a negative reaction with nDNA. This difference in antigen recognition could be due to the presence of antibodies in systemic lupus erythematosus sera against a nuclear antigen different from DNA. In contrast, another patient, although positive for anti-DNA antibody activity, showed a reaction with nuclei. The heterogeneity of systemic lupus erythematosus sera is well documented, and the antibody binding could be due to recognition of single stranded regions in $\mathrm{nDNA}$ which are practically impossible to remove totally. With this technique, antibodies were readily detected, with maximal reactivity at a' serum dilution of $1: 1000$; this is a significantly higher titre than the $1: 100$ observed for nDNA binding. 
Examination of various reference sera with known antibody specificities clearly demonstrated the sensitivity of the technique. The most prominent of our finding was a high reactivity towards RNP, Sm, nDNA, nucleolar and Scl-70 sera, with end point titres higher than in the FANA assay (tab. 1).

In summary, the method described for detection of antinuclear antibodies is a reliable alternative to FANA. It is more convenient to perform, and it produces quantitative, reproducible data, with a high degree of accuracy that is acceptable for most serological assays involving serial dilution of serum.

\section{Acknowledgement}

This work was supported by a research grant to R. A. from the Indian Council of Medical Research, New Delhi [5/12(5)/86BMS-II (8605160)]. The authors are grateful to Mr. Khurshid Alam for providing anti-DNA antibody binding data of systemic lupus erythematosus sera.

\title{
References
}

1. Gripenberg, M. \& Kurki, P. (1986) Demonstration of Human Autoantibodies by Quantitative Enzyme Immunoassays. J. Immunol. Methods 92, 145-160.

2. Ishaq, M. \& Ali, R. (1983) Enzyme-linked Immunosorbent Assay for Detection of Antibodies to Extractable Nuclear Antigens in Systemic Lupus Erythematosus, with Nylon as Solid Phase. Clin. Chem. 29, 823-827.

3. Kumar, A. \& Ali, R. (1984) Detection of Anti-RNA Antibodies in Systemic Lupus Erythematosus by ELISA Using Nylon as Solid Support. Immunol. Lett. 7, 293-296.

4. Ali, A. \& Ali, R. (1986) Anti-DNA Antibodies in Autoimmune Disorders by ELISA Using Nylon as the Solid Phase. Clin. Biochem. 19, 205-208.

5. Ali, A. \& Ali, R. (1983) Enzyme-Linked Immunosorbent Assay for Anti-DNA Antibodies Using Fluorogenic and Colorigenic Substrates. J. Immunol. Methods 56, $341-$ 346.

6. Tan, E. M.. Cohen, A. S., Fries, J. F., Masi, A. T., McShane, D. J., Rothfield, N. F., Schaller, J. G., Talal, N. \& Winchester, R. J. (1982) Revised Criteria for the Classification of Systemic Lupus Erythematosus. Arth. Rheum. 25, $1271-1277$.

7. Ishaq, M., Ali, A., Malaviya, A. N. \& Ali, R. (1982) Studies on Precipitating and Hemagglutinating Antibodies in Systemic Lupus Erythematosus. J. Biosci. 4, 499-506.

8. Ishaq, M. \& Ali, R. (1983) Purification and Identification of Antigenic Polypeptides of $\mathrm{Sm}$ and RNP Antigens of Goat Liver. Biochem. Biophys. Res. Commun. 114, 564570.

9. Aotsuka, S., Okawa, M., Ibeke, K. \& Yakohari, R. (1979) Measurement of Anti-Double Stranded DNA Antibodies in Major Immunoglobulin Classes. J. Immunol. Methods $28,149-162$.

10. Coons, A. H. \& Kaplan, M. H. (1950) Localization of Antigen in Tissue Cells: II Improvements in a Method for Detection of Antigens by Means of Fluorescent Antibody. J. Exp. Med. 91, 1-16.

11. Molden, D. P., Nakamura, R. M. \& Tan, E. M. (1984) Standardization of the Immunofluorescent Test for Autoantibody to Nuclear Antigens (ANA): Use of Reference Sera of Defined Specificity. Am. J. Clin. Pathol. 82, 57-66.

12. Beutner, E. M. (1975) Defined Immunofluorescent Staining. Ann. N. Y. Acad. Sci. 254, 873.

\author{
Dr. Rashid Ali \\ Department of Biochemistry \\ Jawaharlal Nehru Medical College \\ Aligarh Muslim University Aligarh 202002 \\ India
}


. 